\title{
Article \\ MA-XRF for the Characterisation of the Painting Materials and Technique of the Entombment of Christ by Rogier van der Weyden
}

\author{
Anna Mazzinghi ${ }^{1,2, * \mathbb{C}}$, Chiara Ruberto ${ }^{1,2}$, Lisa Castelli ${ }^{2}$, Caroline Czelusniak ${ }^{2}$, Lorenzo Giuntini ${ }^{1,2} \mathbb{D}$, \\ Pier Andrea Mandò ${ }^{1,2}$ and Francesco Taccetti ${ }^{2}$ \\ 1 Department of Physics and Astronomy, Università Degli Studi di Firenze, 50019 Sesto Fiorentino, Italy; \\ ruberto@fi.infn.it (C.R.); giuntini@fi.infn.it (L.G.); mando@fi.infn.it (P.A.M.) \\ 2 Florence Division, INFN/CHNet, 50019 Sesto Fiorentino, Italy; castelli@fi.infn.it (L.C.); \\ czelusniak@fi.infn.it (C.C.); ftaccetti@fi.infn.it (F.T.) \\ * Correspondence: mazzinghi@fi.infn.it
}

check for updates

Citation: Mazzinghi, A.; Ruberto, C.; Castelli, L.; Czelusniak, C.; Giuntini, L.; Mandò, P.A.; Taccetti, F. MA-XRF for the Characterisation of the Painting Materials and Technique of the Entombment of Christ by Rogier van der Weyden. Appl. Sci. 2021, 11, 6151. https://doi.org/10.3390/ app11136151

Academic Editor: Letizia Bonizzon

Received: 5 June 2021

Accepted: 28 June 2021

Published: 2 July 2021

Publisher's Note: MDPI stays neutral with regard to jurisdictional claims in published maps and institutional affiliations.

Copyright: (C) 2021 by the authors Licensee MDPI, Basel, Switzerland. This article is an open access article distributed under the terms and conditions of the Creative Commons Attribution (CC BY) license (https:/ / creativecommons.org/licenses/by/ $4.0 /)$

\begin{abstract}
At present, macro X-ray fluorescence (MA-XRF) is one of the most essential analytical methods exploited by heritage science. By providing spatial distribution elemental maps, not only does it allow for material characterisation but also to understand, or at least to have a likely idea of, the production techniques of an analysed object. INFN-CHNet, the Cultural Heritage Network of the Italian National Institute of Nuclear Physics, designed and developed a MA-XRF scanner aiming to be a lightweight, easy to transport piece of equipment for use in in situ measurements. In this study, the INFN-CHNet MA-XRF scanner was employed for the analysis of a painting by the Flemish artist Rogier van der Weyden. The painting belongs to the collection of the Uffizi gallery in Florence and was analysed during conservation treatments at the Opificio delle Pietre Dure, one of the main conservation centres in Italy. The research aims were to characterise the materials employed by the artist and to possibly understand his painting technique. Although MA-XRF alone cannot provide a comprehensive characterisation, it nonetheless proved to be an invaluable tool for providing an initial overview or hypothesis of the painting materials and techniques used.
\end{abstract}

Keywords: MA-XRF; heritage science; non-invasive analysis; portable equipment; pigment identification; van der Weyden; Flemish painting; calco-potassic glass in painting; INFN-CHNet; Opificio delle Pietre Dure

\section{Introduction}

Macro X-ray fluorescence mapping, widely known as MA-XRF in the scientific community [1], is now one of the most valuable tools aiding the heritage science field. MA-XRF analysis produces elemental distribution maps of a scanned area of an object, proving to be exceptionally useful not only for material characterisation but also for understanding an artist's painting and production techniques. In addition, mapping makes it easier to associate trace elements with a specific colour or area, even in noisy maps, with respect to a "traditional" single point measurement. Moreover, as MA-XRF renders not only spectra but also images, it can also be easily adopted by non-X-ray experts, such as conservators or art historians.

The technique is relatively fast; the acquisition time naturally depends on the dimensions of the area of analysis and the dimensions and characteristics of the instrument employed. Numerous types of equipment are available nowadays, ranging from small and easy-to-transport instruments customized for the analysis of areas of only a few $\mathrm{cm}^{2}[2,3]$ to massive scanners allowing large areas to be analysed in a reasonably short acquisition time [4-6].

Numerous successful applications of MA-XRF in heritage science have now been described in many papers. Many of these applications involve the analysis of paintings [7-10], 
but these applications also range from manuscripts [11,12], painted papers [13], metals [14], glasses [15], tiles [16], and archaeological sites [17] to furniture [18] and many others.

The research presented here used the MA-XRF scanner specifically designed and developed for heritage science by INFN-CHNet, the Cultural Heritage Network of the Italian National Institute of Nuclear Physics [19-21]. There are several partners within this network, one of these being the Opificio delle Pietre Dure (OPD) in Florence, a reputable conservation centre belonging to the Italian Ministry of Cultural Heritage. The Florence division of INFN works in close and fruitful collaboration with OPD, mainly for the analysis of paintings. One of these is the focus of this work, a painting produced by the famous Flemish painter known as Rogier van der Weyden, who was active in the first half of the XV century. This painting, the Entombment of Christ, belongs to the collection of the Uffizi gallery in Florence and was likely painted in 1460. The main aim of this work was to gain further information on the painting palette and techniques used by van der Weyden, comparing these results with those from other works by the artist, as specifically described in the results section. The materials analysis also aimed at supporting the ongoing conservation intervention.

To accomplish this purpose, the INFN-CHNet MA-XRF scanner has been proven to be an invaluable tool for an early non-invasive analysis of the elemental composition of the materials, the most of which could be reasonably hypothesised. Needless to say, MA-XRF alone cannot conclusively identify most of the pigments or other materials and thus cannot ascertain their exact nature. Other analytical methods are indeed routinely employed in combination with a comprehensive material characterisation. It is, however, true that MA-XRF analysis allows for a relatively fast and complete analysis able to provide, at the very least, a first overview or hypothesis of the materials and techniques employed by the artist, as will be demonstrated in this work. These results can be considered a first reliable basis for material identification and may act as an guide for the use of consecutive analytical methods.

\section{Materials and Methods}

\subsection{The Entombment of Christ by Rogier van der Weyden}

Rogier van der Weyden, also known as Rogier de la Pasture, is considered one of the most important and influential Flemish painters of his time, among contemporaries such as Jan van Eyck. He was born in Tournai in 1399 and settled in Brussels during 1435, becoming the official painter of the city in just three years, where he died in 1464 [22]. Both masters were innovative, primarily for their use of multiple thin transparent oil layers that achieved unprecedented colour intensities. The technique also gave them the ability to carefully paint fine and minute details, as can be seen, for example, in detailed decorations of precious textiles or in the abundance of naturalistic details of extremely realistic-looking scenes. Rogier van der Weyden not only demonstrated his technical skills in naturalistic detail, but also added emotions as an important element of the naturalism of characters, painting people moved to tears and covering their faces to express their grief or sorrow. These features are clearly visible in the Entombment of Christ from the Uffizi (Figure 1), which was possibly commissioned by the Medici family for their Villa at Careggi, near to Florence [23]. Moreover, it is likely that the Medici were one of the artist's Italian clients [22]. Indeed, the fame of the Netherlandish artist had spread throughout Europe by the middle of the 15th century, and he also travelled to Italy in 1450 where he most likely encountered Italian artists and works of art. It is therefore realistic that his growing fame attracted an increasing demand for his work and that he needed the aid of several skilled assistants [24]. This is one of the reasons why works by van der Weyden are rarely securely identified as his own, as he had a very large productive workshop in Brussels, and in those times works were not signed by artists. It is thus often difficult to separate the master's unaided work from that of his assistants and imitators [25]. 


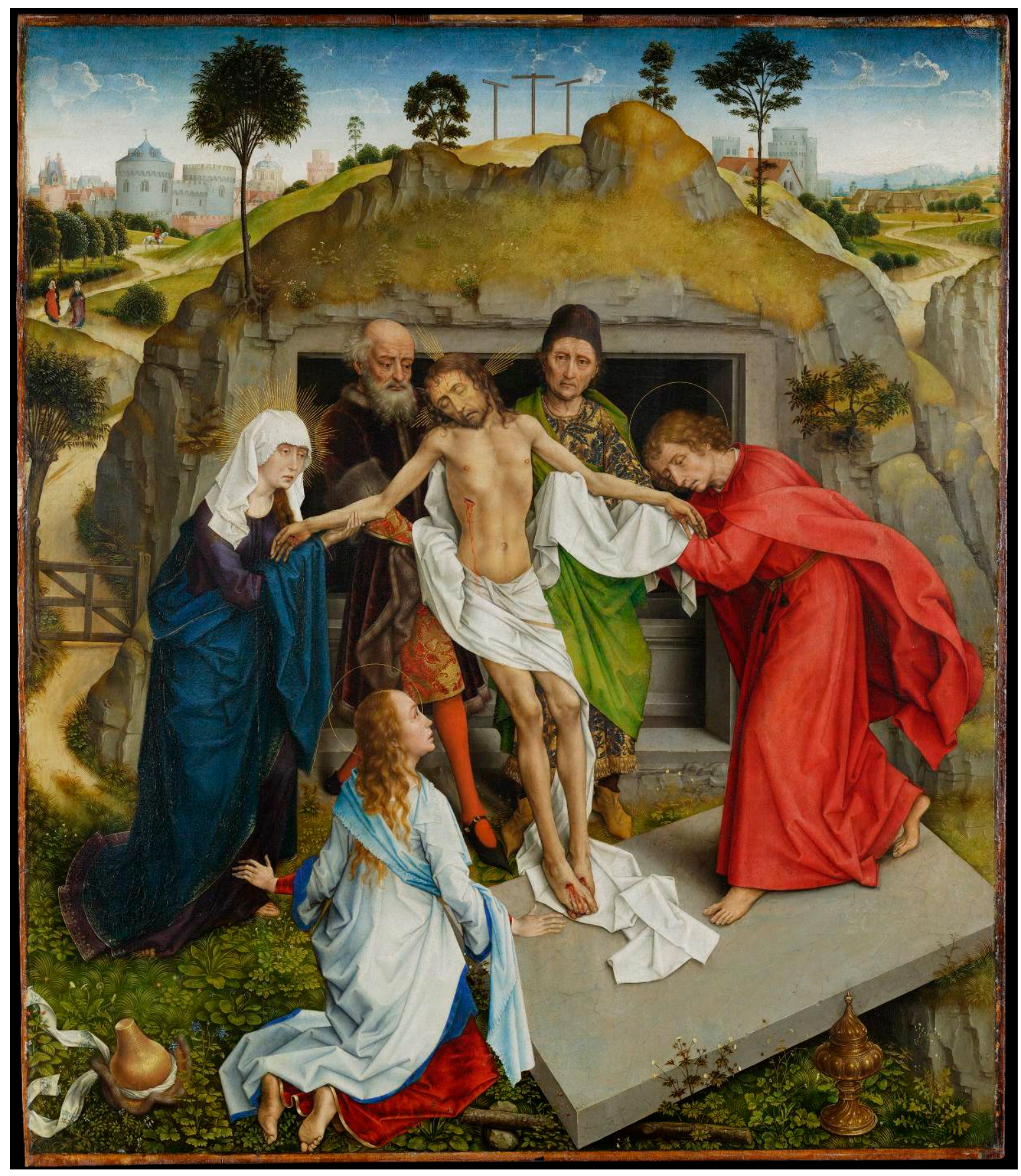

Figure 1. The Entombment of Christ by Rogier van der Weyden.

This painting represents the burial of Christ with the Virgin and Saint John the Evangelist holding his hands (Figure 1). The body is supported by Joseph of Arimathea (an old man at Christ's proper right) and Nicodemus (the man dressed in green at Christ's proper left); kneeling Magdalene is in the lower foreground. The scene takes place in front of the tomb located on a rocky and hilly landscape with a city in the distance. Two Marys are on their way to the tomb in the left side of the background. The scheme of the scene is possibly inspired by the predella painted by Beato Angelico [23] depicting the Deposition of Christ, a painting that van der Weyden most likely saw in Florence during his travel in Italy.

The painting (oil on panel) is in pristine condition, and the most recent conservation intervention at the OPD was aimed mainly at a superficial treatment in the occasion of an exhibition at the Mauritshuis in 2018 [26]. 


\subsection{The INFN-CHNet MA-XRF Scanner}

The instrument was designed with a special focus on portability and lightness. The technical characteristics and analytical capabilities (detection efficiency, spatial resolution, etc.) of this equipment are thoroughly described in [27]. Briefly, the measuring head of the instrument was composed of an X-ray tube (Moxtek, $40 \mathrm{kV}$ maximum voltage, $0.1 \mathrm{~mA}$ maximum anode current) and a Silicon Drift Detector (Amptek XR100 SDD, $25 \mathrm{~mm}^{2}$ effective active surface, $500 \mu \mathrm{m}$ thickness). A telemeter (Keyence IA-100) that was also installed on the measuring head, acted for the control and adjustment of the sample-instrument distance during the scan. This measuring head was mounted on three linear motor stages by Physik Instrumente, with a $200 \mathrm{~mm}$ travel range in the $\mathrm{x}$ and $\mathrm{y}$ directions for this version, plus a $50 \mathrm{~mm}$ stage along the $\mathrm{z}$ perpendicular direction. This was all installed on a carbon-fibre box containing motor controllers, a signal digitizer (CAEN DT5780), and other auxiliary elements. The software controlling acquisition and data analysis was developed by INFN-CHNet. The instrument has been successfully employed in several heritage science applications over the years [28-30].

During the analysis discussed here, the operating conditions of the $\mathrm{X}$-ray tube for all measurements were: $30 \mathrm{kV}$ anode voltage, $0.1 \mathrm{~mA}$ filament current, and a Mo anode with an $800 \mu \mathrm{m}$ diameter collimator. The scanning velocity ranged from 1 to $2 \mathrm{~mm} / \mathrm{s}$ and the equivalent pixel size ranged from 200 to $1000 \mu \mathrm{m}$. Typical measuring conditions, which are those used in the maps shown in this paper, were a scanning speed of $1 \mathrm{~mm} / \mathrm{s}$ and a pixel size of $1 \mathrm{~mm}$. Different parameters are specified when needed in the Supplementary Materials.

\section{Results and Discussion}

In the present study, several areas were analysed to investigate the materials employed in this painting. The materials identified/hypothesised are broadly consistent with those that were available to artists in the second half of the 15th century. The most interesting areas of analysis and corresponding XRF maps will be shown and discussed in detail in this paragraph. Other areas and maps can be found in the Supplementary Materials.

$\mathrm{Pb}$ is present almost ubiquitously in the painting, or at least in the areas analysed, most likely in the form of lead white used in mixtures with other pigments and dyes to achieve lighter hues. Lead white was possibly employed also in the imprimitura layer, as happened commonly in paintings during those times and frequently in Flemish paintings after the second quarter of the fifteenth century (as consistent with the dating of the painting) [31]. Furthermore, calcite traces in lead white were found by de Viguerie et al. [32] in other works by Rogier van der Weyden. In this painting, the presence of $\mathrm{Ca}$ associated to lead white could not be conclusively established as, for different reasons as will be further discussed, Ca is likely present also in other pigments/colours.

Blue areas, such as those of the Virgin's and Magdalene's robes-the former with intense hue and the latter in a pale tone-or the blue damask decorations of Nicodemus (see discussed later and Figure S1, at higher spatial resolution), are characterised by the presence of $\mathrm{Cu}$, most likely indicating the use of azurite, rather than other $\mathrm{Cu}$-based blue pigments such as blue verditer or Egyptian blue, as found in other works by the artist (Figure 2) [33]. Zn traces associated with these $\mathrm{Cu}$-based areas are consistent, though not common [34], with traces detected in some cases in azurite, corroborating the hypothesis [35] (see Figure S2). Possibly, the few X-ray counts of Ca detected in these blue areas might also be related to calcite traces in azurite [36] (see Figure S1), though it cannot be specifically excluded that the Ca detected is also due to the gypsum-based preparation layer. 
(a)
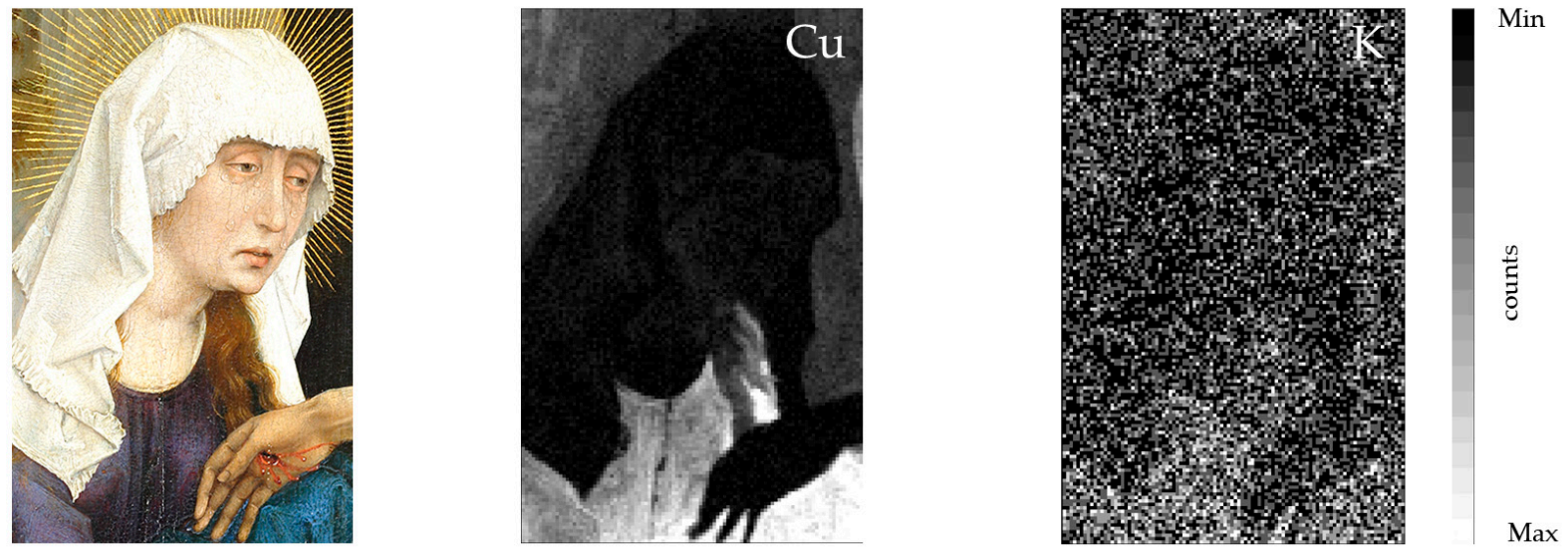

(b)
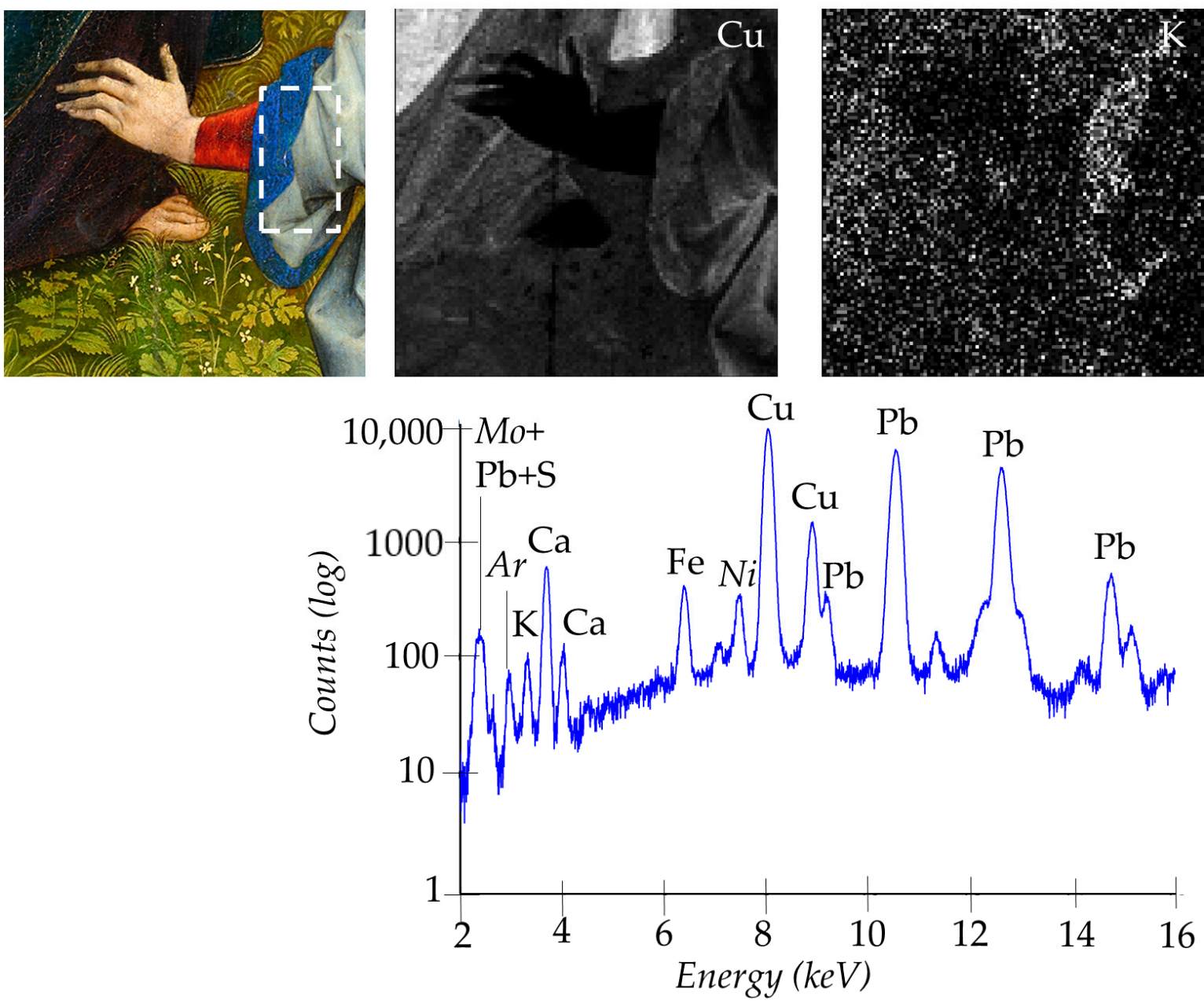

Figure 2. (a) Detail of the blue and purple Virgin's robe, with relative $\mathrm{Cu}(\mathrm{K} \alpha)$ and $\mathrm{K}(\mathrm{K}) \mathrm{XRF}$ maps; (b) detail of Magdalene's robe (with purple and blue Virgin's robe on the back), with relative $\mathrm{Cu}(\mathrm{K} \alpha)$ and $\mathrm{K}(\mathrm{K}) \mathrm{XRF}$ maps; (c) spectrum of the blue sleeve of Mary Magdalene (relative to the dashed area in detail (b)). Detected Ni is due to impurities in the X-ray tube, Mo is due to the X-ray tube anode, and Ar is due to the air path.

In those times, it was common to use an azurite underpaint layer beneath a more expensive ultramarine thin layer [37], a practice also attested to other works by Rogier van der Weyden [33,38]. The distribution of K maps, though present in traces, may suggest that this layering also occurs in the Entombment from the Uffizi (Figure 2). Indeed, $\mathrm{K}$, though not specifically present in the blue mineral lazurite principal component 
of ultramarine, is characteristic of this precious pigment, as it takes part in the production process [39,40].

$\mathrm{Cu}$-based compounds, possibly azurite anew, were also contained in the deep purple robe of the Virgin (Figure 2) and in the reddish/amaranth mantle of Joseph of Arimathea (Figure 3). Most likely, azurite was mixed with variable amounts of organic dye(s) to obtain these different hues, as might be hypothesised by the detection of $\mathrm{K}$ traces in the purple robe of the Virgin (Figure 2), characteristic of the alum commonly employed in the production process of organic dyes and lakes [41]. At the same time, it seems unlikely that in this case $\mathrm{K}$ indicates the use of the expensive ultramarine in such a hue, although it cannot be completely excluded. Iron oxides/hydroxides compounds (possibly earth or ochres) are also present in small amounts (Figure 3). Instead, no $\mathrm{Hg}$ was detected in these areas, however it was used in the fur trimming of Joseph of Arimathea's mantle together with the Fe-based compounds and lead white (Figure 3).

(a)

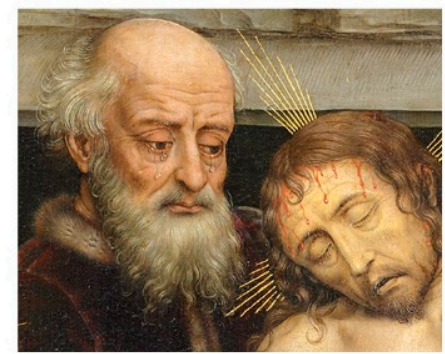

(b)

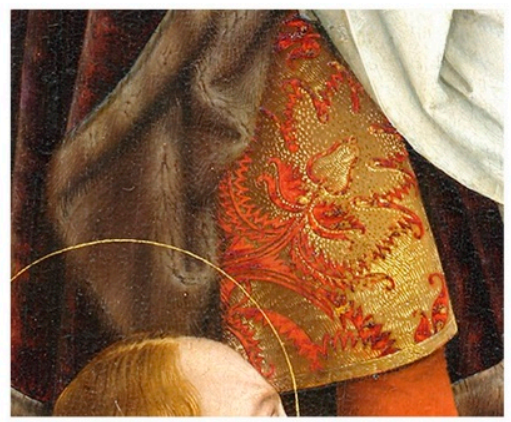

Min

Max
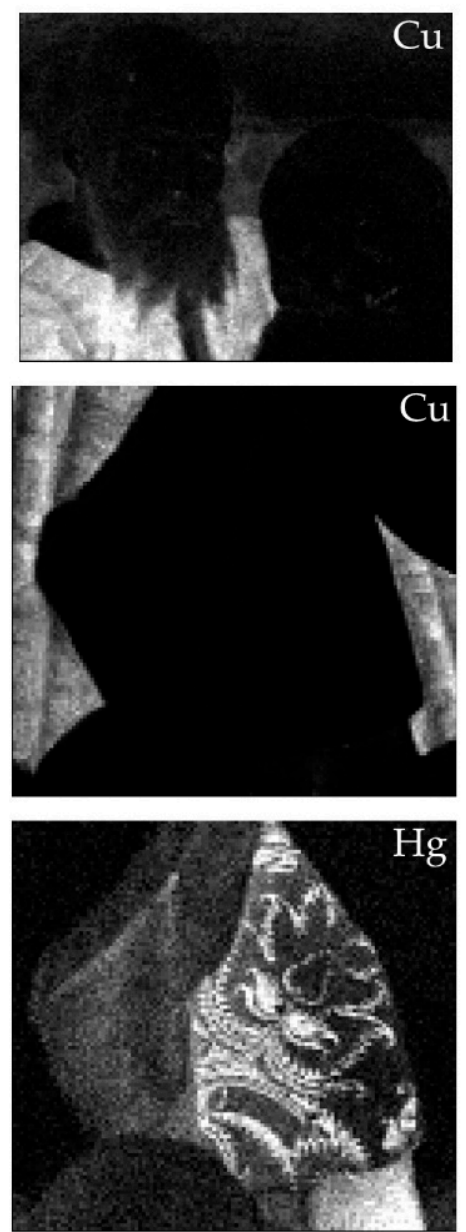
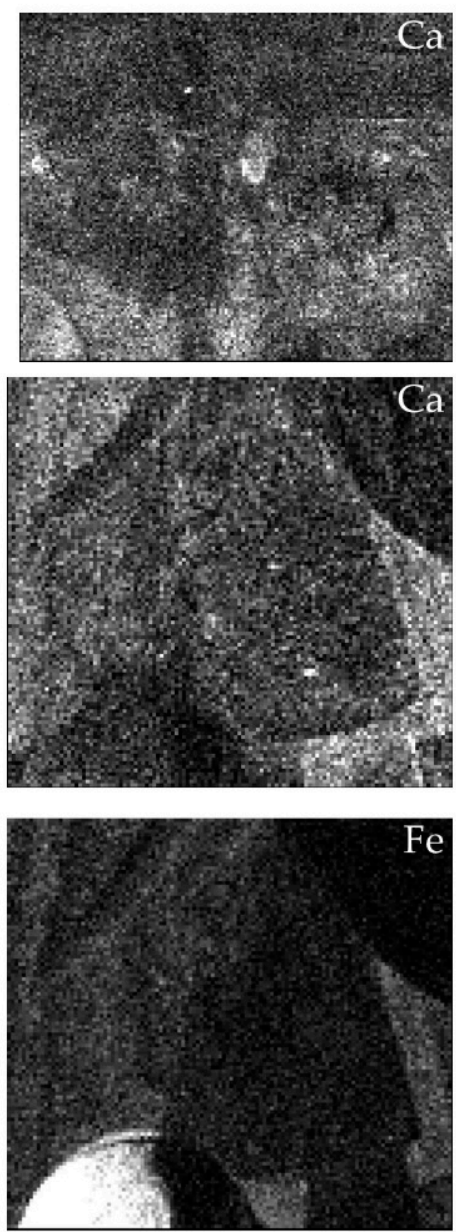

Figure 3. (a) Detail of the red/amaranth robe of Joseph of Arimathea, with relative $\mathrm{Cu}(\mathrm{K} \alpha)$ and $\mathrm{Ca}(\mathrm{K} \alpha) \mathrm{XRF}$ maps; (b) detail of the red/amaranth robe of Joseph of Arimathea (lower part), with relative $\mathrm{Cu}(\mathrm{K} \alpha), \mathrm{Fe}(\mathrm{K} \alpha), \operatorname{Hg}(\mathrm{L} \alpha)$, and $\mathrm{Ca}(\mathrm{K} \alpha) \mathrm{XRF}$ maps.

Ca was also detected in association with these purple/reddish areas (Figure 3) and might be related to the gypsum preparation layer, as discussed earlier. However, it cannot be excluded that it might also be due to the use of glass as an additive in the painting layer. Powdered glass, acting most likely as a drier/siccative of the oil medium, was indeed used extensively by artists, particularly between the fifteenth and sixteenth centuries in Italy and in Northern European works [42-44]. It was particularly suitable for red lakes, as it does not affect the typical transparency of these materials. In Netherlandish paintings, calco-potassic glasses were common, in which the main constituents (other 
than silica) are variable amounts of $\mathrm{Ca}$ and $\mathrm{K}$ due to ashes and/or lime used in the production process [45], with lower amounts of Mn in comparison to glasses used in Italian paintings [46]. Interestingly, it is documented that finely ground Ca-rich glasses were also used as additives by van der Weyden [33].

The red garment of John the Evangelist, together with other small red areas of the robe of one of the two Marys in the left side of the background landscape, are characterised by the presence of $\mathrm{Hg}$, indicating the use of vermilion (Figure 4) as well as red damask decorations on Joseph of Arimathea's robe (Figures 3 and S1, at higher spatial resolution). Modelling was obtained by means of $\mathrm{Cu}$ - and Fe oxides/hydroxide-based compounds (both present in low quantities), as similarly happens in other garments (Figure 4). The red roof of the building on the right side of the background was painted with a mixture, or overlay, of vermilion with Fe-based compounds (See Figure S3). Vermilion areas are associated with Zn traces, as is commonly attested to this pigment [47] (see Supplementary Materials S4). It is worth noting that Ca was detected in association with red draperies and robes, especially in the deepest shadows, and is well visible in the red robe of Saint John the Evangelist and in the red sleeve of Magdalene (Figures 4 and S4). The presence of Ca in these areas may suggest anew, as previously discussed, the possible presence of Ca-rich glass as an additive in the red lakes used in the modelling of red draperies, as also attested in other works by van der Weyden [25].

(a)

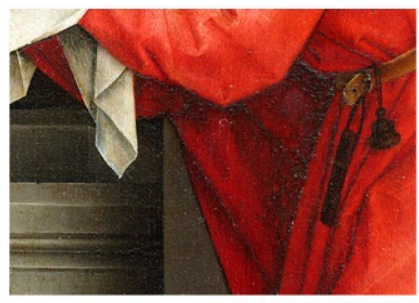

(b)

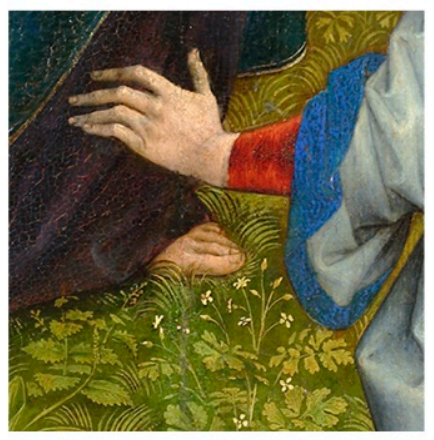

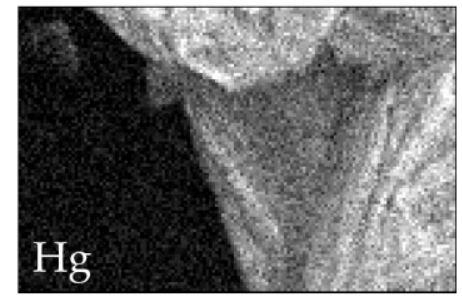
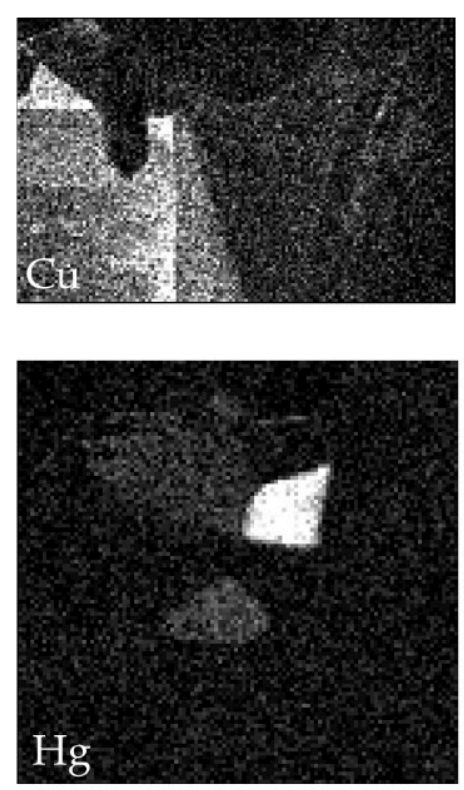
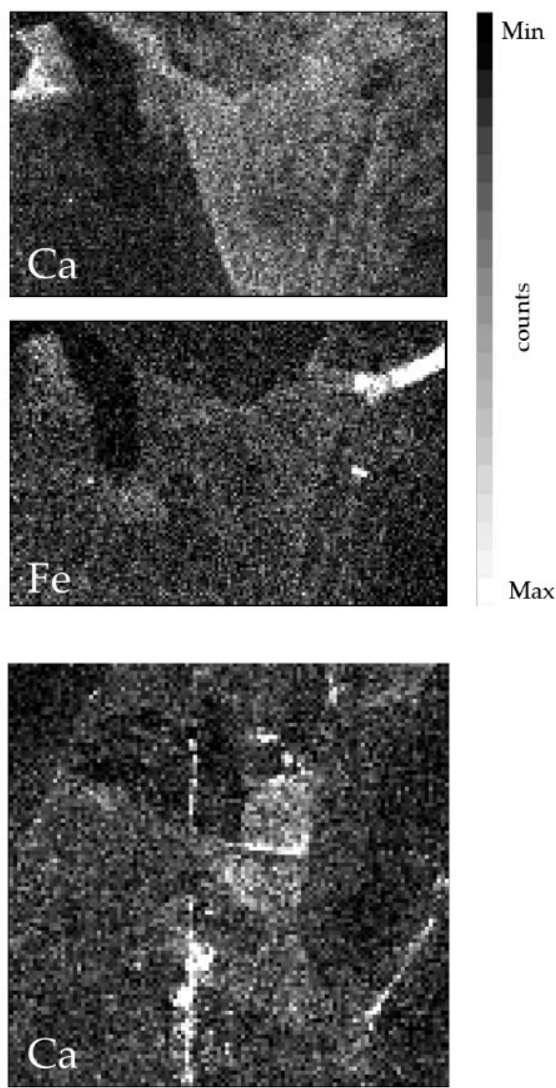

Figure 4. (a) Detail of the red robe of John the Evangelist, with relative $\mathrm{Hg}(\mathrm{L} \alpha), \mathrm{Ca}(\mathrm{K} \alpha), \mathrm{Cu}(\mathrm{K} \alpha)$, and $\mathrm{Fe}(\mathrm{K} \alpha) \mathrm{XRF}$ maps; (b) detail of the red sleeve of Magdalene, with relative $\operatorname{Hg}(\operatorname{L} \alpha)$ and $\mathrm{Ca}(\mathrm{K} \alpha)$ XRF maps.

$\mathrm{Cu}$ is also characteristic of the green garment of Nicodemus (Figure 5). A wide range of $\mathrm{Cu}$-based greens was available in those times and cannot be conclusively identified by means of XRF alone. It is worth noting, however, that verdigris and copper sulphates were detected in other paintings by van der Weyden [38,42]. Sn was also detected in association with this $\mathrm{Cu}$-based green robe, attesting the likely use of lead-tin yellow in modelling 
(Figure 5). Lead-tin yellow was also employed in the golden damask robes of Nicodemus and Joseph of Arimathea, where vermilion and Fe-based compounds were employed for modelling (Figure 5, showing Nicodemus' robe). Green vegetation, grass, and trees were painted with $\mathrm{Cu}$-based compounds and lead-tin yellow as well, not necessarily in mixture but possibly employed in layers to build the volumes of the landscape (Figure 5). Small amounts of Fe-based compounds were also detected, likely not in association with $\mathrm{K}$ and thus in principle excluding the use of green earth. Ca was also detected in some cases in association with trees, a presence that could not be conclusively understood (see Figure S5). It can be hypothesised that the artist made the use of lakes (with powdered glass anew) or of ivory/bone black, though its presence is difficult to confirm with XRF alone, as will be further discussed.

$\mathrm{Cu}$-based pigments and vermilion were also employed in light blue/grey and pink background architectures, respectively (see Figure S3).

Flesh tones were painted using lead white and vermilion with details and outlines obtained with Fe-based pigments. Cu-based compounds were employed, in small amounts, in the shadows and eyes (Figures 5, 6, S2 and S6; the latter at higher spatial resolution where the use of vermilion was highlighted in tiny detail such as the red lacrimal caruncle of the eye). Hair was obtained with a complex mixture of vermilion, Fe- and $\mathrm{Cu}$ - based compounds, as well as lead-tin yellow (Figures 6, S2 and S5), where different hair tones were obtained with various mixtures of these pigments. In grey hair, such as that of Joseph of Arimathea, mainly Cu-based pigments and lead white were employed, together with small quantities of lead-tin yellow (Figure 6). The blood drops on Christ's forehead were painted with vermilion (Figure 6).

Golden lines representing the halos or rays around the character's heads were realised with gold (Figures 6 and S2). Any distribution of other elements leads to the thought of the presence of a preparation layer, though the golden lines are so thin that associations with their distribution could not be properly evaluated. Upon visual inspection, gildings were likely applied using the mission technique.

The rocks and cave of the burial were painted in grey/dark tones. $\mathrm{Cu}$ is characteristic of these areas (Figure 6) together with Zn traces, as previously discussed for the blue areas. Darker tones of the cave entrance were painted with the evident addition of Fe-based pigments (Figures 5 and 6). The black hat of Nicodemus was painted with a similar mixture, with the addition of a significant amount of $\mathrm{Ca}$ (Figure 5), which was also detected in the darker zones of the cave (Figure 5). P could not be detected in these areas; thus, it seems unlikely that van der Weyden used bone/ivory black, although its presence cannot be conclusively excluded. P XRF detection efficiency is indeed rather low, especially on varnished paintings. In addition, there was a partial overlap of the escape peak of the $\mathrm{Ca} \mathrm{K} \alpha \mathrm{X}$-ray line with that of $\mathrm{P}$, further encumbering its detection. It is also possible that the artist added some lakes, with Ca-rich glass, to warm this black hue. 
(a)
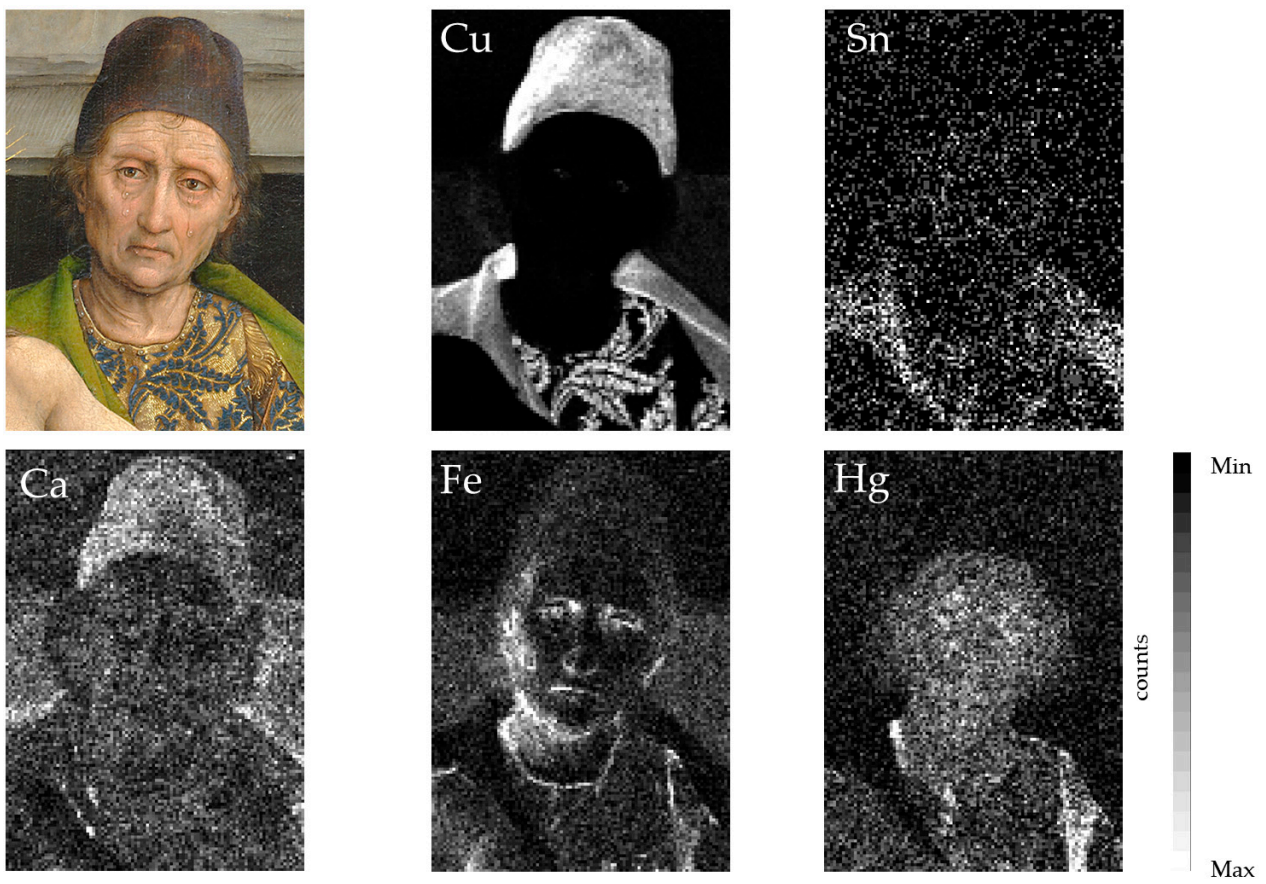

(b)
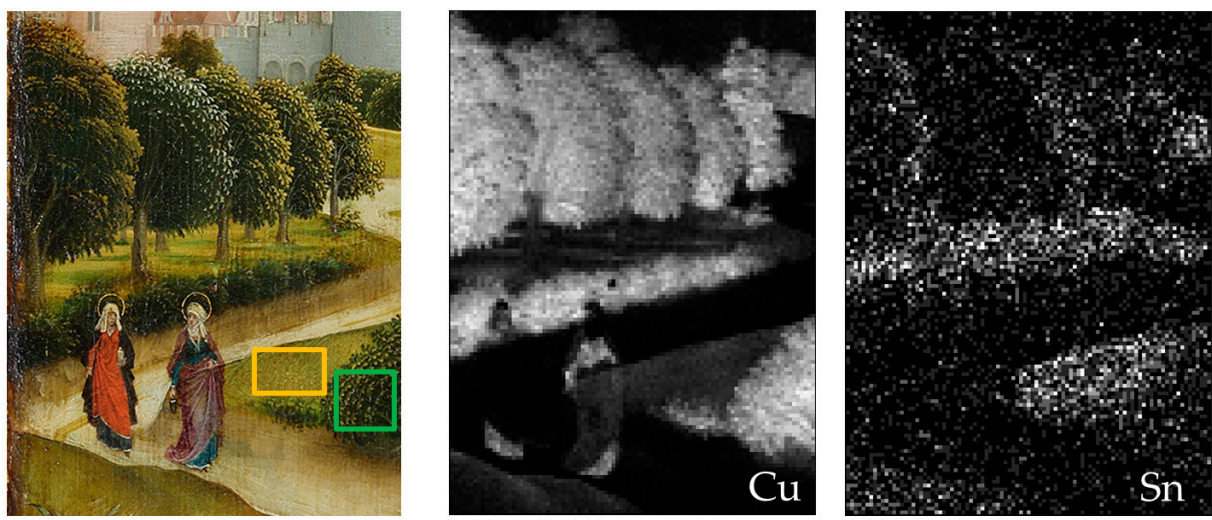

$\operatorname{Max}$

(c)

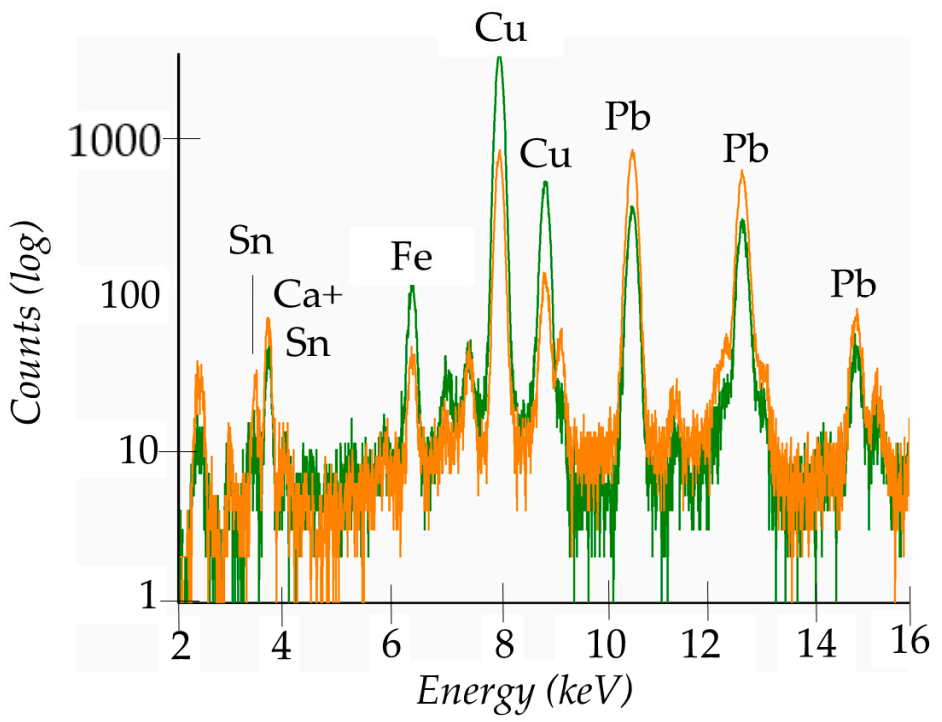

Figure 5. (a) Detail of Nicodemus, with relative $\mathrm{Cu}(\mathrm{K} \alpha), \mathrm{Sn}(\mathrm{L} \alpha), \mathrm{Ca}(\mathrm{K} \alpha), \mathrm{Fe}(\mathrm{K} \alpha)$, and $\mathrm{Hg}(\mathrm{L} \alpha) \mathrm{XRF}$ maps; (b) detail of the upper left landscape, with relative $\mathrm{Cu}(\mathrm{K} \alpha)$ and $\mathrm{Sn}(\mathrm{L} \alpha)$ XRF maps; (c) spectra of the green and yellowish landscape, relative to the areas indicated in detail $(\mathbf{b})$. The two ROI are roughly of the same area in pixels. 

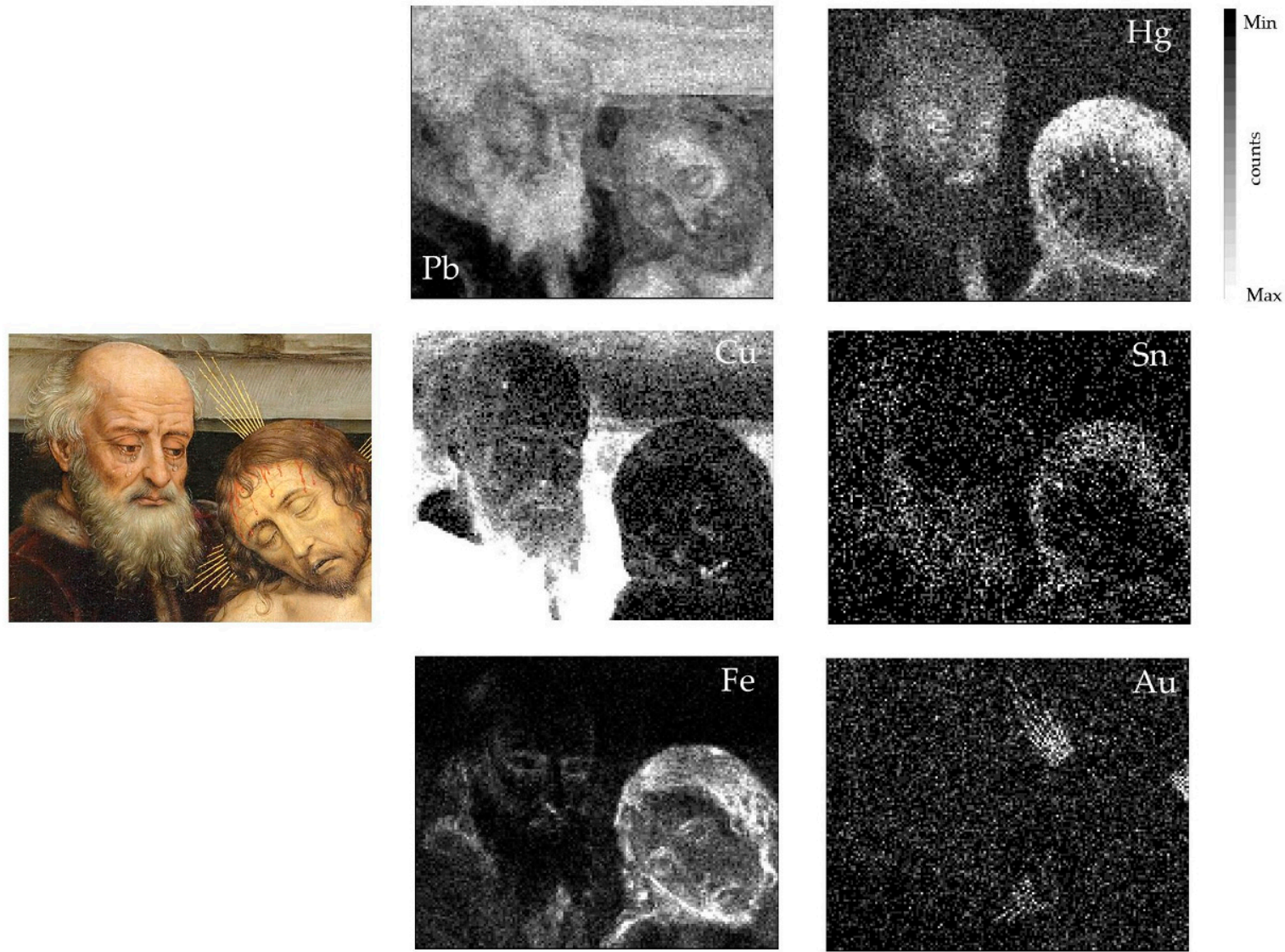

Figure 6. Detail of Joseph of Arimathea and Christ, with relative $\mathrm{Pb}(\mathrm{L} \alpha), \mathrm{Hg}(\mathrm{L} \alpha), \mathrm{Fe}(\mathrm{K} \alpha), \mathrm{Cu}(\mathrm{K} \alpha), \operatorname{Sn}(\mathrm{L} \alpha)$, and $\mathrm{Au}(\mathrm{L} \alpha)$ $\mathrm{XRF}$ maps. The grey scale in the $\mathrm{Cu}$ map is edited to enhance the distribution in flesh tones and hair.

\section{Conclusions}

The imaging approach of MA-XRF employed in this study allowed to obtain information regarding the materials and techniques used by Rogier van der Weyden in his Entombment of Christ. With a degree of uncertainty due to the technique itself, traditional materials were determined or hypothesised by XRF. These include azurite, ultramarine, lead-white, vermilion, $\mathrm{Cu}$-based green, $\mathrm{Fe}$ oxides/hydroxides (earth/ochres), lead-tin yellow, and gold (in thin lines in halos). The detection of Ca traces associated with some areas possibly suggests the use of dyes or lakes in which a calco-potassic glass, present as a drier/siccative, is consistent with the Flemish technique during those times. Although committed by the Medici's family, this result may also in principle confirm the Flemish production of the painting and exclude the possibility that it was painted in Florence during the artists' journey to Italy, as the Italian glass used for this purpose were Mn-rich rather than Ca-rich.

As it has been demonstrated also in this study, MA-XRF allows the non-invasive mapping of the distribution of the different painting materials in sufficient detail, but at the same time it is true that unfortunately it lacks the specificity for a comprehensive characterisation of all materials. It is indeed highly recommended to combine, when available, other analytical methods for an accurate identification of the compounds. However, MA-XRF is undoubtedly a powerful technique which is a source of relevant information, especially when employed as an early non-invasive and non-destructive analytical method acting as a guide for a subsequent more accurate scientific analysis.

Supplementary Materials: The following are available online at https:/ / www.mdpi.com/article/10 .3390/app11136151/s1: Figure S1: (a) Detail of the damask robe of Joseph of Arimathea, with relative $\mathrm{Hg}(\mathrm{L} \alpha)$ and $\mathrm{Pb}(\mathrm{L} \alpha)$ XRF maps; (b) Detail of the damask robe of Nicodemus, with relative $\mathrm{Cu}(\mathrm{L} \alpha)$, 
$\mathrm{K}(\mathrm{K} \alpha), \mathrm{Hg}(\mathrm{L} \alpha), \mathrm{Sn}(\mathrm{L} \alpha)$ and $\mathrm{Ca}(\mathrm{K} \alpha)$ XRF maps. Measuring conditions (both areas): scanning speed $2 \mathrm{~mm} / \mathrm{s}$, pixel size $250 \mu \mathrm{m}$. Figure S2: Detail of the Virgin, with relative $\mathrm{Pb}(\mathrm{L} \alpha), \mathrm{Fe}(\mathrm{K} \alpha), \mathrm{Au}(\mathrm{L} \alpha)$, $\mathrm{Hg}(\mathrm{L} \alpha)$, and $\mathrm{Zn}(\mathrm{K} \alpha)$ XRF maps. Figure S3: Detail of the city in the far right of the background, with relative $\mathrm{Hg}(\mathrm{L} \alpha), \mathrm{Fe}(\mathrm{K} \alpha), \mathrm{Ca}(\mathrm{K} \alpha), \mathrm{Cu}(\mathrm{K} \alpha)$, and $\mathrm{Sn}(\mathrm{L} \alpha)$ XRF maps. Figure S4: Detail of Magdalene, with relative $\mathrm{Pb}(\mathrm{L} \alpha), \mathrm{Fe}(\mathrm{K} \alpha), \mathrm{Hg}(\mathrm{L} \alpha), \mathrm{Sn}(\mathrm{L} \alpha), \mathrm{Zn}(\mathrm{K} \alpha)$ and $\mathrm{Ca}(\mathrm{K} \alpha)$ XRF maps. Figure S5: Detail of the upper left landscape, with relative $\mathrm{Ca}(\mathrm{L} \alpha), \mathrm{Fe}(\mathrm{K} \alpha), \mathrm{Pb}(\mathrm{L} \alpha)$ and $\mathrm{Zn}(\mathrm{K} \alpha)$ XRF maps. Figure S6: Detail of the eyes of John the Evangelist, with relative $\mathrm{Fe}(\mathrm{K} \alpha), \operatorname{Hg}(\mathrm{K} \alpha), \mathrm{Pb}(\mathrm{L} \alpha)$ and $\mathrm{Cu}(\mathrm{K} \alpha) \mathrm{XRF}$ maps. Measuring conditions: scanning speed $2 \mathrm{~mm} / \mathrm{s}$, pixel size $250 \mu \mathrm{m}$.

Author Contributions: Conceptualization, A.M., C.R., L.C.; methodology, F.T., L.G., P.A.M.; software, F.T., C.C., L.C.; validation, P.A.M.; formal analysis, A.M., C.R.; investigation, A.M., C.R.; resources, F.T., L.G., P.A.M.; data curation, F.T., C.C., L.C.; writing-original draft preparation, A.M.; writing-review and editing, A.M., L.C., C.R., L.G.; visualization, A.M., C.R., L.C.; supervision, F.T., P.A.M.; project administration, F.T. All authors have read and agreed to the published version of the manuscript.

Funding: This research received no external funding.

Acknowledgments: The authors are grateful to the Opificio delle Pietre Dure and the Gallerie degli Uffizi for allowing this study. In particular, Cecilia Frosinini, Roberto Bellucci, Chiara Rossi, Chiara Modesti (OPD), Eike D. Schmidt and Carolina Forasassi (Uffizi) are gratefully acknowledged. Authors warmly thank Lara Palla for her contribution to the MA-XRF software. Thanks are also due to Marco Manetti for his invaluable technical support and to Leandro Sottili for his helpful suggestions.

Conflicts of Interest: The authors declare no conflict of interest.

\section{References}

1. Alfeld, M. MA-XRF for Historical Paintings: State of the Art and Perspective. Microsc. Microanal. 2020, 26, 72-75. [CrossRef]

2. Galli, A.; Caccia, M.; Alberti, R.; Bonizzoni, L.; Aresi, N.; Frizzi, T.; Bombelli, L.; Gironda, M.; Martini, M. Discovering the material palette of the artist: A p-XRF stratigraphic study of the Giotto panel 'God the Father with Angels'. X-ray Spectrom. 2017, 46, 435-441. [CrossRef]

3. Alfeld, M.; Mulliez, M.; Martinez, P.; Cain, K.; Jockey, P.; Walter, P. The Eye of the Medusa: XRF Imaging Reveals Unknown Traces of Antique Polychromy. Anal. Chem. 2017, 89, 1493-1500. [CrossRef] [PubMed]

4. Alfeld, M.; Pedroso, J.V.; Hommes, M.V.E.; Van der Snickt, G.; Tauber, G.; Blaas, J.; Haschke, M.; Erler, K.; Dik, J.; Janssens, K. A mobile instrument for in situ scanning macro-XRF investigation of historical paintings. J. Anal. At. Spectrom. 2013, 28, 760-767. [CrossRef]

5. Romano, F.P.; Caliri, C.; Nicotra, P.; Di Martino, S.; Pappalardo, L.; Rizzo, F.; Santos, H.C. Real-time elemental imaging of large dimension paintings with a novel mobile macro X-ray fluorescence (MA-XRF) scanning technique. J. Anal. At. Spectrom. 2017, 32, 773-781. [CrossRef]

6. Pouyet, E.; Barbi, N.; Chopp, H.; Healy, O.; Katsaggelos, A.; Moak, S.; Mott, R.; Vermeulen, M.; Walton, M. Development of a highly mobile and versatile large MA-XRF scanner for in situ analyses of painted work of arts. X-ray Spectrom. 2021, 50, 263-271. [CrossRef]

7. Saverwyns, S.; Currie, C.; Delgado, E.L. Macro X-ray fluorescence scanning (MA-XRF) as tool in the authentication of paintings. Microchem. J. 2018, 137, 139-147. [CrossRef]

8. Reiche, I.; Eveno, M.; Müller, K.; Calligaro, T.; Pichon, L.; Laval, E.; Mysak, E.; Mottin, B. New insights into the painting stratigraphy of L'Homme blessé by Gustave Courbet combining scanning macro-XRF and confocal micro-XRF. Appl. Phys. A 2016, 122, 947. [CrossRef]

9. Ravaud, E.; Pichon, L.; Laval, E.; Gonzalez, V.; Eveno, M.; Calligaro, T. Development of a versatile XRF scanner for the elemental imaging of paintworks. Appl. Phys. A 2016, 122, 1-7. [CrossRef]

10. Delaney, J.K.; Dooley, K.A.; Van Loon, A.; Vandivere, A. Mapping the pigment distribution of Vermeer's Girl with a Pearl Earring. Herit. Sci. 2020, 8, 1-16. [CrossRef]

11. Ricciardi, P.; Legrand, S.; Bertolotti, G.; Janssens, K. Macro X-ray fluorescence (MA-XRF) scanning of illuminated manuscript fragments: Potentialities and challenges. Microchem. J. 2016, 124, 785-791. [CrossRef]

12. Ricciardi, P.; Mazzinghi, A.; Legnaioli, S.; Ruberto, C.; Castelli, L. The Choir Books of San Giorgio Maggiore in Venice: Results of in Depth Non-Invasive Analyses. Heritage 2019, 2, 103. [CrossRef]

13. Clarke, M.L.; Gabrieli, F.; Rowberg, K.L.; Hare, A.; Ueda, J.; McCarthy, B.; Delaney, J.K. Imaging spectroscopies to characterize a 13th century Japanese handscroll, The Miraculous Interventions of Jizō Bosatsu. Herit. Sci. 2021, 9, 1-10. [CrossRef]

14. MacLennan, D.; Llewellyn, L.; Delaney, J.K.; Dooley, K.A.; Patterson, C.S.; Szafran, Y.; Trentelman, K. Visualizing and measuring gold leaf in fourteenth- and fifteenth-century Italian gold ground paintings using scanning macro X-ray fluorescence spectroscopy: A new tool for advancing art historical research. Herit. Sci. 2019, 7, 25. [CrossRef] 
15. Legrand, S.; Van der Snickt, G.; Cagno, S.; Caen, J.; Janssens, K. MA-XRF imaging as a tool to characterize the 16th century heraldic stained-glass panels in Ghent Saint Bavo Cathedral. J. Cult. Herit. 2019, 40, 163-168. [CrossRef]

16. Lins, S.; Manso, M.; Lins, P.; Brunetti, A.; Sodo, A.; Gigante, G.; Fabbri, A.; Branchini, P.; Tortora, L.; Ridolfi, S. Modular MA-XRF Scanner Development in the Multi-Analytical Characterisation of a 17th Century Azulejo from Portugal. Sensors 2021, 21, 1913. [CrossRef]

17. Alfeld, M.; Baraldi, C.; Gamberini, M.C.; Walter, P. Investigation of the pigment use in the Tomb of the Reliefs and other tombs in the Etruscan Banditaccia Necropolis. X-ray Spectrom. 2019, 48, 262-273. [CrossRef]

18. Sottili, L.; Guidorzi, L.; Mazzinghi, A.; Ruberto, C.; Castelli, L.; Czelusniak, C.; Giuntini, L.; Massi, M.; Taccetti, F.; Nervo, M.; et al. The Importance of Being Versatile: INFN-CHNet MA-XRF Scanner on Furniture at the CCR “La Venaria Reale". Appl. Sci. 2021, 11, 1197. [CrossRef]

19. INFN-CHNet. Available online: http://chnet.infn.it/en/who-we-are-2/ (accessed on 29 April 2021).

20. Chiari, M.; Barone, S.; Bombini, A.; Calzolai, G.; Carraresi, L.; Castelli, L.; Czelusniak, C.; Fedi, M.E.; Gelli, N.; Giambi, F.; et al. LABEC, the INFN ion beam laboratory of nuclear techniques for environment and cultural heritage. Eur. Phys. J. Plus 2021, 136, 1-28. [CrossRef]

21. Giuntini, L.; Castelli, L.; Massi, M.; Fedi, M.; Czelusniak, C.; Gelli, N.; Liccioli, L.; Giambi, F.; Ruberto, C.; Mazzinghi, A.; et al. Detectors and Cultural Heritage: The INFN-CHNet Experience. Appl. Sci. 2021, 11, 3462. [CrossRef]

22. Campbell, L. Rogier van der Weyden and his Workshop. Proc. Br. Acad. 1994, 84, 1-24.

23. van Suchtelen, A. A painting from Florence, in Mauritshuis infocus. Rogier van der Weyden Unvelied 2018, 2, 14-15.

24. Kemperdick, S. Rogier van der Weyden's Workshop around 1440. In Rogier van der Weyden in Context: Proceedings of Symposium XVII, Leuven, November 2009 (Underdrawing and Technology in Painting. Symposia); Campbell, L., Van Der Stock, J., Reynolds, C., Watteeuw, L., Eds.; Peeters Publishers: Paris, France; Leuven, Belgium; Walpole, MA, USA, 2012; pp. 57-77.

25. Billinge, R.; Campbell, L.; Dunkerton, J.; Foister, S.; Kirby, J.; Pilc, J.; Roy, A.; Spring, M.; White, R. The materials and technique of five paintings by Rogier van der Weyden and his Workshop. Nat. Gallery Tech. Bull. 1997, 18, 68-86.

26. Rogier van der Weyden Unveiled. Available online: https://www.mauritshuis.nl/en/discover/exhibitions/rogier-van-derweyden-unveiled (accessed on 10 May 2021).

27. Taccetti, F.; Castelli, L.; Czelusniak, C.; Gelli, N.; Mazzinghi, A.; Palla, L.; Ruberto, C.; Censori, C.; Giudice, A.L.; Re, A.; et al. A multipurpose X-ray fluorescence scanner developed for in situ analysis. Rend. Lince. 2019, 30, 307-322. [CrossRef]

28. Ruberto, C.; Mazzinghi, A.; Massi, M.; Castelli, L.; Czelusniak, C.; Palla, L.; Gelli, N.; Betuzzi, M.; Impallaria, A.; Brancaccio, R.; et al. Imaging study of Raffaello's “La Muta” by a portable XRF spectrometer. Microchem. J. 2016, 126, 63-69. [CrossRef]

29. Mazzinghi, A.; Ruberto, C.; Castelli, L.; Ricciardi, P.; Czelusniak, C.; Giuntini, L.; Mandò, P.A.; Manetti, M.; Palla, L.; Taccetti, F. The importance of being little: MA-XRF on manuscripts on a Venetian island. X-ray Spectrom. 2021, 50, 272-278. [CrossRef]

30. Vadrucci, M.; Mazzinghi, A.; Sorrentino, B.; Falzone, S.; Gioia, C.; Gioia, P.; Loreti, E.M.; Chiari, M. Characterisation of ancient Roman wall-painting fragments using non-destructive IBA and MA-XRF techniques. X-ray Spectrom. 2020, 49, 668-678. [CrossRef]

31. Stols, M. Grounds. 1400-1900. In Conservation of Easel Paintings, 2nd ed.; Stoner, J.H., Rushfield, R., Eds.; Routledge Publisher: Oxfordshire, England, 2020; pp. 161-188, ISBN 9780367023799.

32. de Viguerie, L.; Glanville, H.; Ducouret, G.; Jacquemot, P.; Dang, P.; Walter, P. Re-interpretation of the Old Masters' practices through optical and rheological investigation: The presence of calcite. Comptes Rendus Phys. 2018, 19, 543-552. [CrossRef]

33. Spring, M. The Materials of Rogier van der Weyden and his contemporaries in context. In Rogier van der Weyden in Context: Proceedings of Symposium XVII, Leuven, November 2009 (Underdrawing and Technology in Painting. Symposia); Campbell, L., van Der Stock, J., Reynolds, C., Watteeuw, L., Eds.; Peeters Publishers: Paris, France; Leuven, Belgium; Walpole, MA, USA, 2012; pp. 93-105.

34. Smieska, L.M.; Mullett, R.; Ferri, L.; Woll, A.R. Trace elements in natural azurite pigments found in illuminated manuscript leaves investigated by synchrotron x-ray fluorescence and diffraction mapping. Appl. Phys. A 2017, 123. [CrossRef]

35. Delaney, J.K.; Ricciardi, P.; Deming Glinsman, L.; Facini, M.; Thoury, M.; Palmer, M.; de la Rie, E.R. Use of imaging spectroscopy, fiber optic reflectance spectroscopy, and X-ray fluorescence to map and identify pigments in illuminated manuscripts. Stud. Conserv. 2014, 59, 91-101. [CrossRef]

36. Aru, M.; Burgio, L.; Rumsey, M.S. Mineral impurities in azurite pigments: Artistic or natural selection? J. Raman Spectr. 2014, 45, 1013-1018. [CrossRef]

37. Cennini, C. Chapter CXLVI, Come dèi fare vestiri di azzurro, d'oro, o di porpora. In Il Libro dell'Arte, o Trattato della Pittura; Milanesi, G., Milanesi, C., Eds.; Le Monnier: Firenze, Italy, 1859.

38. Keune, K.; Boon, J.J. Imaging Secondary Ion Mass Spectrometry of a paint cross section taken from an Early Netherlandish painting by Rogier van der Weyden. Anal. Chem. 2004, 76, 1374-1385. [CrossRef]

39. Ganio, M.; Pouyet, E.S.; Webb, S.M.; Schmidt Patterson, C.M.; Walton, M.S. From lapis lazuli to ultramarine blue: Investigating Cennino Cennini's recipe using sulfur K-edge XANES. Pure Appl. Chem. 2018, 90, 463-475. [CrossRef]

40. Gambardella, A.A.; Marine, C.; de Nolf, W.; Schnetz, K.; Erdmann, R.; van Elsas, R.; Gonzalez, V.; Wallert, A.; Iedema, P.D.; Eveno, M.; et al. Sulfur K-edge micro- and full-field XANES identify marker for preparation method of ultramarine pigment from lapis lazuli in historical paints. Sci. Adv. 2020, 6, eaay8782. [CrossRef] 
41. Kirby, J.; Spring, M.; Higgitt, C. The Technology of Red Lake Pigment Manufacture: Study of the Dyestuff Substrate. Natl. Gallery Tech. Bull. 2005, 26, 71-87.

42. Lutzenberger, K.; Stege, H.; Tilenschi, C. A note on glass and silica in oil paintings from the 15th to the 17th century. J. Cult. Herit. 2010, 11, 365-372. [CrossRef]

43. Spring, M. New insights into the materials of fifteenth- and sixteenth-century Netherlandish paintings in the National Gallery, London. Herit. Sci. 2017, 5, 40. [CrossRef]

44. Mazzinghi, A.; Ruberto, C.; Castelli, L.; Czelusniak, C.; Taccetti, F.; Mandò, P.A. Indagini XRF a scansione sul Ritratto di papa Leone X con i cugini cardinali. In Raffaello e il Ritorno del Papa Medici: Restauri e Scoperte sul Ritratto di Leone X con i due Cardinali; Ciatti, M., Schmidt, E.D., Eds.; Edifir Edizioni Firenze: Firenze, Italy, 2020; Volume 54, pp. 219-226.

45. Wedepohl, K.H.; Simon, K. The chemical composition of medieval wood ash glass from Central Europe. Geochemistry 2010, 70, 89-97. [CrossRef]

46. Spring, M. Colourless Powdered Glass as an Additive in Fifteenth- and Sixteenth-Century European Paintings. Natl. Gallery Tech. Bull. 2012, 33, 4-26.

47. Gettens, R.J.; Feller, R.L.; Chase, W.T. Vermilion and Cinnabar. Stud. Cons. 1972, 17, 45-69. 